UCEs in termites

\title{
1 Using ultraconserved elements to reconstruct the termite tree of life
}

2

3 Running title: UCEs in termites

4

5 Simon Hellemans ${ }^{1, *}$, Menglin Wang ${ }^{1}$, Nonno Hasegawa ${ }^{1}$, Jan Šobotník $^{2}$, Rudolf H. Scheffrahn ${ }^{3}$,

6 Thomas Bourguignon ${ }^{1,2, *}$

7

$8{ }^{1}$ Okinawa Institute of Science \& Technology Graduate University, 1919-1 Tancha, Onna-son,

9 Okinawa 904-0495, Japan.

$10 \quad{ }^{2}$ Faculty of Tropical AgriScience, Czech University of Life Sciences, Kamýcka 129, 16521

11 Prague, Czech Republic.

$12{ }^{3}$ Fort Lauderdale Research and Education Center, Institute for Food and Agricultural Sciences,

133205 College Avenue, Davie, Florida 33314 USA.

14

$15 *$ Corresponding authors: simon.hellemans@gmail.com (SH); Thomas.Bourguignon@oist.jp

$16(\mathrm{~TB})$ 
UCEs in termites

\section{ORCID references of authors}

18

19

20

21

Simon Hellemans: 0000-0003-1266-9134

Menglin Wang: 0000-0003-2206-9503

Nonno Hasegawa: 0000-0001-5149-9129

Jan Šobotník: 0000-0002-8581-637X

Rudolf H. Scheffrahn: 0000-0002-6191-5963

Thomas Bourguignon: 0000-0002-4035-8977

\section{Author contributions}

SH and TB conceptualized the experiments. JS and RS collected the samples. MW performed lab experiments and generated data. $\mathrm{SH}, \mathrm{MW}$ and $\mathrm{NH}$ analyzed the data. $\mathrm{SH}$ and $\mathrm{TB}$ wrote the manuscript.

\section{Competing interests}

We declare we have no competing interests.

\section{Funding}

This work was supported by Czech Science Foundation (project No. 15-07015Y), by the Internal Grant Agency of the Faculty of Tropical AgriSciences, CULS (20213112), by the Japan Society for the Promotion of Science JSPS through a postdoctoral fellowship for foreign 
bioRxiv preprint doi: https://doi.org/10.1101/2021.12.09.472027; this version posted December $17,2021$. The copyright holder for this preprint (which was not certified by peer review) is the author/funder, who has granted bioRxiv a license to display the preprint in perpetuity. It is made available under aCC-BY-NC-ND 4.0 International license.

UCEs in termites

37 researchers awarded to SH (19F19819), and by the Okinawa Institute of Science and

Technology through core unit funding.

39

\section{Acknowledgments}

41 We thank Yves Roisin, Saran Traoré and Guy Josens for providing specimens as well as Crystal

42 Clitheroe for helping with DNA extraction and library preparation. We also thank the Scientific 43 Computation and Data Analysis Section (SCDA) of the Okinawa Institute of Science and 44 Technology Graduate University, Okinawa, Japan, for providing access to the OIST computing 45 cluster.

\section{Electronic Supplementary Materials}

Additional information is available for this manuscript.

\section{Data Archiving}

51 The data that support the findings of this study will be deposited in GenBank (see

52 Supplementary Table S1 for details). Bait sequences, as well as the extracted UCE sequences,

53 will be deposited on Dryad (Supplementary Data 1-7). 
bioRxiv preprint doi: https://doi.org/10.1101/2021.12.09.472027; this version posted December 17, 2021. The copyright holder for this preprint (which was not certified by peer review) is the author/funder, who has granted bioRxiv a license to display the preprint in perpetuity. It is made available under aCC-BY-NC-ND 4.0 International license.

UCEs in termites

54

55

56

57

58

59

60

61

62

63

64

65

66

67

68

69

70

71 Key words: Data Mining; Isoptera; Phylogenomics; Mitochondrial genome; Nuclear genome;

\section{Abstract}

The phylogenetic history of termites has been investigated using mitochondrial genomes and transcriptomes. However, both sets of markers have specific limitations. Mitochondrial genomes represent a single genetic marker likely to yield phylogenetic trees presenting incongruences with species trees, and transcriptomes can only be obtained from well-preserved samples. In contrast, ultraconserved elements (UCEs) include a great many independent markers that can be retrieved from poorly preserved samples. Here, we designed termitespecific baits targeting 50,616 UCE loci. We tested our UCE bait set on 42 samples of termites and three samples of Cryptocercus, for which we generated low-coverage highly-fragmented genome assemblies and successfully extracted in silico between 3,426 to 42,860 non-duplicated UCEs per sample. Our maximum likelihood phylogenetic tree, reconstructed using the 5,934 UCE loci retrieved from upward of $75 \%$ of samples, was congruent with transcriptome-based phylogenies, demonstrating that our UCE bait set is reliable and phylogenetically informative. Combined with non-destructive DNA extraction protocols, our UCE bait set provides the tool needed to carry out a global taxonomic revision of termites based on poorly preserved specimens such as old museum samples. The Termite UCE database is maintained at: https://github.com/oist/TER-UCE-DB/. Taxonomy. 
bioRxiv preprint doi: https://doi.org/10.1101/2021.12.09.472027; this version posted December 17, 2021. The copyright holder for this preprint (which was not certified by peer review) is the author/funder, who has granted bioRxiv a license to display the preprint in perpetuity. It is made available under aCC-BY-NC-ND 4.0 International license.

UCEs in termites

\section{Introduction}

Termites are the most ancient lineage of social insects, with a fossil record dating back to the Early Cretaceous, 135 million years ago (Mya) (Thorne et al., 2000; Grimaldi \& Engel, 2005; Engel et al., 2009). All modern termites share a common ancestor estimated at 140-150 Mya by time-calibrated phylogenetic trees (Bourguignon et al., 2015; Bucek et al., 2019). However, the bulk of the modern termite species diversity belongs to the Termitidae, a lineage that originated during the early Eocene, $~ 50$ Mya, as indicated by time-calibrated phylogenetic trees (Bourguignon et al., 2015, 2017; Bucek et al., 2019) and by the fossil record (Engel et al., 2011). While the backbone of the phylogenetic tree of termites is now largely resolved, most termite species are still awaiting to be placed on the tree of life.

Our understanding of the phylogenetic history of termites was mostly based on mitochondrial markers and fossils to calibrate estimated times of divergence until Bucek et al. (2019) published a phylogenetic tree of termites based on transcriptome data. The first phylogenetic trees of termites were based on a couple of PCR-amplified mitochondrial markers, sometimes combined with nuclear $18 \mathrm{~S}$ or $28 \mathrm{~S}$ sequences and/or morphological characters, which hardly contributed to any phylogenetic signal (e.g., Lo et al., 2004; Inward et al., 2007; Legendre et al., 2008). These phylogenies provided a good overview of the relationships among the main termite lineages but lacked the robustness of phylogenetic trees inferred from full mitochondrial genomes (e.g., Cameron et al., 2012; Bourguignon et al., 2015, 2017). Full mitochondrial genomes, which became easy to sequence with the rise of second-generation sequencing technologies, resolve both shallow and deep divergences in the evolutionary history of termites and other insect lineages (Cameron, 2014), making them a marker of choice for phylogenetic reconstructions. However, mitochondrial genomes form a single marker, as all mitochondrial genes are linked and maternally inherited as a single package. Consequently, mitochondrial phylogenies are sometimes discordant with species phylogenies, especially for 
bioRxiv preprint doi: https://doi.org/10.1101/2021.12.09.472027; this version posted December 17, 2021. The copyright holder for this preprint (which was not certified by peer review) is the author/funder, who has granted bioRxiv a license to display the preprint in perpetuity. It is made available under aCC-BY-NC-ND 4.0 International license.

UCEs in termites

closely related species and short internal branches that diverged in periods of time too brief for alleles to coalesce (Whitfield \& Lockhart, 2007; Degnan \& Rosenberg, 2009). One example of such discordance is provided by Sphaerotermitinae, the unambiguous sister group of Macrotermitinae according to transcriptomic data; but supported as sister to nonmacrotermitine non-foraminitermitine Termitidae by mitochondrial genome phylogenies (Figure 1; Bucek et al., 2019). Phylogenies based on multiple independent nuclear markers are needed to resolve the evolutionary history of organisms accurately.

Transcriptomes, the snapshot of genes expressed by an organism during tissue sampling, include many independent nuclear markers that can be used to build robust phylogenetic trees. Transcriptome-based phylogenies, reconstructed using up to $\sim 4,000$ single-copy orthologous nuclear genes spanning over 7.7 million nucleotide positions, have provided a robust picture of the ancient evolutionary history of termites (Bucek et al., 2019). The sequencing of transcriptomes is now affordable, but, unfortunately, RNA is unstable and can only be extracted from samples that have been adequately preserved and stored, preventing the use of most samples collected before the genomic era began and making the approach impractical for largescale studies. One alternative is to mine the conserved genetic markers present in wholegenome shotgun sequencing datasets, such as some datasets generated to sequence mitochondrial genomes.

Ultraconserved Elements (UCEs) are highly conserved nuclear regions whose functions remain largely unknown (Bejerano et al., 2004; Faircloth et al., 2012). UCEs are found across all regions of animal genomes, including the exonic, intronic, and intergenic regions. Phylogenetic trees inferred from UCEs have contributed to our understanding of the evolutionary history of various animal lineages spanning across the animal tree of life (e.g., Faircloth et al., 2012; Ryu et al., 2012; Smith et al., 2014; White \& Braun, 2019; Zhang et al., 2019). Unlike transcriptomes, UCEs can readily be obtained from museum samples through 
bioRxiv preprint doi: https://doi.org/10.1101/2021.12.09.472027; this version posted December 17, 2021. The copyright holder for this preprint (which was not certified by peer review) is the author/funder, who has granted bioRxiv a license to display the preprint in perpetuity. It is made available under aCC-BY-NC-ND 4.0 International license.

UCEs in termites

123 baiting conserved elements and their phylogenetically-informative flanking regions from 124 fragmented genome assemblies (Blaimer et al., 2016; Faircloth, 2017; Derkarabetian et al., 125 2019). No UCE bait set has been designed for termites so far. We filled this gap as follows: $(i)$ 126 we designed in silico baits to capture UCEs; (ii) we compared phylogenetic trees reconstructed 127 using all possible combinations of mitochondrial genomes, nuclear ribosomal RNA genes, and 128 UCEs; and (iii) we showed that UCEs obtained from low-coverage shotgun genome assemblies 129 are an alternative to transcriptome-based phylogenies for the reconstruction of multi-gene 130 phylogenies. Finally, we set up a Termite UCE Database, thereby ensuring a long-term re131 usability of published data.

\section{Material and Methods}

\section{Biological samples and sequencing}

135 We used sequence data from 42 samples of termites and three samples of Cryptocercus, the wood-feeding subsocial cockroach genus forming the sister group of termites. The sequencing

137 data of 14 species were retrieved from previous studies (for details, see Table S1). The 138 sequencing data from the remaining 31 species were obtained from samples preserved in $80 \%$ 139 ethanol stored at room temperature or from samples preserved in RNA-later $®$ and stored at 140 temperatures ranging between $-20^{\circ} \mathrm{C}$ and $-80^{\circ} \mathrm{C}$ until DNA extraction. DNA was extracted using the DNeasy Blood \& Tissue extraction kit (Qiagen). Libraries were prepared using the

143 Dual Indexing Kit (New England Biolabs), with reagent volumes reduced to one-fifteenth of 144 recommended volumes. For samples preserved in $80 \%$ ethanol, libraries were prepared without the enzymatic fragmentation step as the DNA of these samples is typically highly fragmented. 
bioRxiv preprint doi: https://doi.org/10.1101/2021.12.09.472027; this version posted December $17,2021$. The copyright holder for this preprint (which was not certified by peer review) is the author/funder, who has granted bioRxiv a license to display the preprint in perpetuity. It is made available under aCC-BY-NC-ND 4.0 International license.

UCEs in termites

146 Libraries were pooled in equimolar concentration and paired-end sequenced using the Illumina

147 HiSeq X or Novaseq platforms at a read length of $150 \mathrm{bp}$.

UCE loci identification and in silico bait design

150 The identification of UCE loci was carried out using PHYLUCE v1.6.6 (Faircloth, 2016)

151 following the recommendations of the tutorial (https://phyluce.readthedocs.io/en/stable/) and

152 outlined workflow (Faircloth, 2017). Four publicly available genomes belonging to distantly

153 related termite species were used to design baits: Zootermopsis nevadensis (Archotermopsidae),

154 Cryptotermes secundus (Kalotermitidae), Coptotermes formosanus (Rhinotermitidae), and

155 Macrotermes natalensis (Termitidae). Genome completeness was assessed using BUSCO

$156 v 4.1 .2$ (Simão et al., 2015) and QUAST v5.0.2 (Gurevich et al., 2013). The genome of $M$.

157 natalensis was chosen as the base genome for bait design due to its comparatively higher quality

158 (for details, see Table S1).

Repetitive elements, retroelements, transposons, and small RNAs were masked from genome assemblies using RepeatMasker v4.1.1 (Smit et al., 2015) with the command line “species eukaryota -div 50". Assemblies were converted in the 2-bit format using the

162 faToTwoBit tool of the BLAT suite of programs (Kent, 2002). We simulated 100 bp error-free paired-end sequencing reads from the three genome assemblies other than that M. natalensis using art_illumina Q v2.5.8 (Huang et al., 2012) with the command line “--fcov 2 --mflen 200 --sdev 150”. In order to identify orthologous loci representing putative UCEs, the reads 166 simulated from the three termite genome assemblies were mapped independently on the 167 genome assembly of $M$. natalensis with a 0.05 substitution rate onto the base genome using the 168 permissive raw-read aligner Stampy v1.0.32 (Lunter \& Goodson, 2011). The three alignment maps were handled with SAMtools v1.9 (Li et al., 2009) and converted into BED files with 
bioRxiv preprint doi: https://doi.org/10.1101/2021.12.09.472027; this version posted December $17,2021$. The copyright holder for this preprint (which was not certified by peer review) is the author/funder, who has granted bioRxiv a license to display the preprint in perpetuity. It is made available under aCC-BY-NC-ND 4.0 International license.

UCEs in termites

170 bedtools v2.29.2 (Quinlan \& Hall, 2010). In each BED file, putative conserved regions 171 overlapping by at least one nucleotide were merged using bedtools. Conserved sequences 172 shorter than 80 bp or containing over $25 \%$ of masked nucleotides were discarded using the 173 phyluce program phyluce_probe_strip_masked_loci_from_set. The putative orthologous loci 174 found across the four termite genomes were combined into a database using 175 phyluce_probe_get_multi_merge_table (Supplementary Data 1). A total of 175,535 loci shared 176 by the four termite genomes were identified and extracted using

177 phyluce_probe_query_multi_merge_table and

178 phyluce_probe_get_genome_sequences_from_bed, respectively. Extracted UCE sequences 179 shorter than $180 \mathrm{bp}$ were buffered to $180 \mathrm{bp}$ by including 5' and 3' flanking regions in equal 180 amounts with phyluce_probe_get_genome_sequences_from_bed (Supplementary Data 2).

A preliminary set of $120 \mathrm{bp}$ baits was designed from the base genome of $M$. natalensis 182 using phyluce_probe_get_tiled_probes. Baits targeted a region of $180 \mathrm{bp}$ and overlapped in its 183 center by $60 \mathrm{bp}$ (at $2 \mathrm{X}$ tiling density). UCEs with ambiguous base calls and GC-content above $18470 \%$ or below $30 \%$ were discarded from the bait set. Duplicates, defined as sequences having $50 \%$ identity over half of their length, were also removed from the bait set using LASTZ (Harris, 186 2007) implemented in the programs phyluce_probe_easy_lastz and 187 phyluce_probe_remove_duplicate_hits_from_probes_using_lastz. In order to further identify 188 and remove non-specific baits, we aligned the bait set (Supplementary Data 3) to the four 189 genomes with phyluce_probe_run_multiple_lastzs_sqlite using a minimum identity threshold 190 of $80 \%$ and minimum coverage of $83 \%$. Sequences shorter than 180 bp were buffered to 180 191 bp by including 5' and 3' flanking regions in equal amounts and extracted from the alignments 192 using phyluce_probe_slice_sequence_from_genomes. The loci shared by the four termite 193 genomes were identified using phyluce_probe_get_multi_fasta_table and 194 phyluce_probe_query_multi_fasta_table (Supplementary Data 4). The final UCE bait set was 
bioRxiv preprint doi: https://doi.org/10.1101/2021.12.09.472027; this version posted December $17,2021$. The copyright holder for this preprint (which was not certified by peer review) is the author/funder, who has granted bioRxiv a license to display the preprint in perpetuity. It is made available under aCC-BY-NC-ND 4.0 International license.

UCEs in termites

195

196

197

198

199

200

201

202

203

204

205

designed with phyluce_probe_get_tiled_probe_from_multiple_inputs, and duplicates were removed using LASTZ as described above (397,910 baits targeting 50,616 loci; Supplementary Data 5).

Genome assembling and mining of phylogenetic markers

Adapters and low-quality bases were trimmed from raw reads using fastp $v 0.20 .1$ (Chen et al., 2018). Trimmed reads were assembled using metaSPAdes $v 3.13$ (Nurk et al., 2017). The quality and completeness of assemblies were assessed with QUAST and BUSCO (for details, see Table S1). Mitochondrial genome scaffolds were identified in metaSPAdes assemblies and annotated using MitoFinder v1.4 (Allio et al., 2020). Nuclear ribosomal RNA genes (5S, 5.8S, 18S, and 28S) were extracted from metaSPAdes assemblies using barrnap $v 0.9$ (https://github.com/tseemann/barrnap). UCE loci were extracted from metaSPAdes assemblies using the final set of termite baits we designed and the PHYLUCE suite of programs with parameter values set as recommended in the tutorial and previously published studies (Faircloth et al., 2015; Faircloth, 2017; Quattrini et al., 2018). Briefly, baits were aligned to the metaSPAdes assemblies at a minimum similarity threshold of $50 \%$ with phyluce_probe_run_multiple_lastzs_sqlite. Sequences of the metaSPAdes assemblies matching baits were extracted with the flanking 200 bp situated at both the 5' and $3^{\prime}$ ends using phyluce_probe_slice_sequence_from_genomes. Extracted sequences were mapped back to the baits using phyluce_assembly_match_contigs_to_probes with a minimum identity of $80 \%$ over $67 \%$ of bait length to remove duplicates and sequences matching multiple UCE loci (Supplementary Data 6; Contribution \#1 to the Termite UCE Database available at:

\section{https://github.com/oist/TER-UCE-DB/).}


bioRxiv preprint doi: https://doi.org/10.1101/2021.12.09.472027; this version posted December 17, 2021. The copyright holder for this preprint (which was not certified by peer review) is the author/funder, who has granted bioRxiv a license to display the preprint in perpetuity. It is made available under aCC-BY-NC-ND 4.0 International license.

UCEs in termites

Sequence alignment

220

221

222

223

224

225 241 first, second, and third codon positions of protein-coding genes. Nuclear rRNA gene and UCE 242 alignments were given a single partition each. Phylogenetic trees were reconstructed in a

The 13 mitochondrial protein-coding genes, two mitochondrial rRNAs genes, 22 mitochondrial tRNA genes, four nuclear rRNA genes, and UCEs were aligned using MAFFT v7.305 (Katoh \& Standley, 2013). For mitochondrial protein-coding genes, we translated DNA sequences into the corresponding amino acid sequences using the transeq function from EMBOSS v6.6.0 (Rice et al., 2000) and aligned protein sequences with MAFFT. Protein alignments were backtranslated into codon alignments using PAL2NAL v14 (Suyama et al., 2006). The other four types of genes, the mitochondrial rRNAs and tRNA genes, nuclear rRNA genes, and UCEs, were aligned as DNA sequences. UCE loci were aligned using MAFFT implemented in phyluce_align_seqcap_align, and internal trimming was performed under default parameters with Gblocks (Castresana, 2000; Talavera \& Castresana, 2007) implemented in phyluce_align_get_gblocks_trimmed_alignments_from_untrimmed. Loci absent in more than $25 \%$ of taxa were filtered out with phyluce_align_get_only_loci_with_min_taxa. The final UCE supermatrix was exported using phyluce_align_format_nexus_files_for_raxml (Supplementary Data 7). Mitochondrial and nuclear gene alignments were concatenated using FASconCAT-G_v1.04.pl (Kück \& Longo, 2014).

\section{Phylogenetic analyses}

We ran one separate phylogenetic analysis for the mitochondrial genome alignment, the nuclear rRNA alignment, and the UCE alignment. We also ran one phylogenetic analysis for the combined UCE and mitochondrial genome alignments. The mitochondrial genome alignment was separated into five distinct partitions: combined rRNAs, combined tRNAs, and combined 
bioRxiv preprint doi: https://doi.org/10.1101/2021.12.09.472027; this version posted December 17, 2021. The copyright holder for this preprint (which was not certified by peer review) is the author/funder, who has granted bioRxiv a license to display the preprint in perpetuity. It is made available under aCC-BY-NC-ND 4.0 International license.

UCEs in termites

243 maximum likelihood (ML) framework using IQ-TREE $v 1.6 .12$ with 1,000 ultrafast bootstrap 244 replicates (UFB) to assess branch supports (Nguyen et al., 2015; Chernomor et al., 2016; Hoang 245 et al., 2018). The best-fit nucleotide substitution model was selected for each partition with the 246 Bayesian Information Criterion using ModelFinder implemented in IQ-TREE 247 (Kalyaanamoorthy et al., 2017). We calculated a global bootstrap support (GBS) value for each 248 tree by averaging bootstrap values of all nodes. To assess concordance among UCEs, we carried 249 out a multi-gene coalescence analysis with ASTRAL-III v5.7.7 (Zhang et al., 2018) using 250 individual gene trees obtained with IQ-TREE as described above. We allowed polytomies to 251 reduce gene tree biases. Branch supports calculated with ASTRAL represent local posterior 252 probabilities (LPP), which are based on gene tree quartet frequencies (Sayyari \& Mirarab, 2016). 253 Topological conflicts between individual gene trees and the ASTRAL species tree were 254 assessed with PhyParts (Smith et al., 2015) and visualized with PhyPartsPieCharts 255 (https://github.com/mossmatters/phyloscripts/tree/master/phypartspiecharts).

\section{Results}

In silico data mining

The mitochondrial genomes were retrieved from all 42 termite metaSPAdes assemblies. We also retrieved the four nuclear rRNA genes from $84 \%$ of the samples (see Table S1). and 42,860 non-duplicated UCE loci from 42 termite metaSPAdes assemblies (Table S1). The 263 number of non-duplicated UCE loci extracted from the assemblies of Cryptocercus roaches varied between 13,480 and 16,331 . The final supermatrix, complete at $75 \%$ and containing loci 
bioRxiv preprint doi: https://doi.org/10.1101/2021.12.09.472027; this version posted December 17, 2021. The copyright holder for this preprint (which was not certified by peer review) is the author/funder, who has granted bioRxiv a license to display the preprint in perpetuity. It is made available under aCC-BY-NC-ND 4.0 International license.

UCEs in termites

1,677,394 nucleotide positions, 591,343 of which were parsimony-informative. The 45 taxa were represented by 939 to 5,928 loci.

\section{Phylogenetic reconstructions}

Many deep and shallow relationships within termites were poorly resolved by the nuclear rRNA

272 the rRNA alignment from the analysis on combined marker classes. The phylogenetic

273 reconstruction based on mitochondrial genomes resolved most relationships (GBS = 87), except

274 for several nodes within the Serritermitidae, the Rhinotermitidae, and the Termitinae (Figure

275 S2), as previously reported (Bourguignon et al., 2015). The phylogenetic analysis performed

276 exclusively on UCEs provided the most robust phylogenetic tree among the analyses performed

277 on separate marker classes (Figure S3; GBS = 98.59). Combining UCEs and mitochondrial

278 genomes marginally improved the resolution of the phylogenetic reconstruction (Figure 1;

279 Figure S4; GBS = 99.02). The combined phylogenetic reconstruction resolved all nodes with

280 high supports, except for the position of the rhinotermitid Termitogeton planus (UFB = 52 and

281 65, respectively). The phylogenetic analysis with ASTRAL revealed minimal discordance

282 among the 5,934 UCE markers (Figure S5; final normalized quartet score of 0.89) (LPP = 1),

283 except for five of the 42 nodes that presented conflicts among UCE markers. Within the

284 Rhinotermitidae, the nodes corresponding to the split of T. planus and Prorhinotermes simplex

285 displayed moderate concordance among UCE markers (LPP of 0.89 and 0.83 , respectively).

286 Within the Termitidae, the nodes corresponding to the split of Neocapritermes utiariti,

287 Pericapritermes sp. 4, and of Nitiditermes + Cavitermes showed moderate to high levels of

288 discordance (LPP of 0.66, 0.98, and 0.39, respectively). PhyParts analyses on a subset of 1,000

289 gene trees revealed some levels of topological discordances (Figure S6). Nodes with 
bioRxiv preprint doi: https://doi.org/10.1101/2021.12.09.472027; this version posted December 17, 2021. The copyright holder for this preprint (which was not certified by peer review) is the author/funder, who has granted bioRxiv a license to display the preprint in perpetuity. It is made available under aCC-BY-NC-ND 4.0 International license.

UCEs in termites

290 discordance were mostly dominated by a plethora of topologies rather than by a single

291 alternative and uninformative gene trees.

\section{Discussion}

We reconstructed phylogenetic trees for 42 species of termites and three species of

Cryptocercus using three classes of markers: nuclear rRNA genes, mitochondrial genomes, and

UCEs. The performance of the three types of phylogenetic markers decreased along the

sequence: UCEs, mitochondrial genomes, and nuclear rRNA genes. The phylogenetic tree

inferred from the latter class of markers, the nuclear rRNA genes, was poorly resolved and did

to all other termites. The phylogenetic tree inferred from mitochondrial genomes was robust

but failed to retrieve Sphaerotermitinae as sister to Macrotermitinae, as previously reported

(Bourguignon et al., 2015; Bucek et al., 2019). The best phylogenetic tree was that

well when reconstructing phylogenetic relationships among termite species. The addition of

309 for lineages of Rhinotermitidae and Termitidae whose phylogenetic position was also

310 unresolved with transcriptomic data (Bucek et al., 2019). We used 5,934 UCE loci, a large

311 number of markers that inevitably led to topological discordances between individual UCE

312 trees and the species tree. These discordances are possibly caused by the lack of phylogenetic

313 signal present in a single UCE marker and by population-level processes, such as incomplete 
bioRxiv preprint doi: https://doi.org/10.1101/2021.12.09.472027; this version posted December 17, 2021. The copyright holder for this preprint (which was not certified by peer review) is the author/funder, who has granted bioRxiv a license to display the preprint in perpetuity. It is made available under aCC-BY-NC-ND 4.0 International license.

UCEs in termites

314 lineage sorting and introgression, which frequently occurs during the emergence of new 315 lineages (Degnan \& Rosenberg, 2009; Blom et al., 2017; Parins-Fukuchi et al., 2021). The 316 actual relationships among termite lineages with unresolved positions remain unclear, possibly 317 reflecting intricate evolutionary history that cannot be satisfactorily resolved by molecular 318 phylogenetic techniques.

We ran our analyses on samples for which we generated low coverage genome assemblies. Notably, we retrieved numerous UCE sequences for all samples, including many 321 that produced highly fragmented assemblies with low BUSCO scores (for details, see Table 322 S1). All samples were accurately placed on the phylogenetic tree. Therefore, our UCE bait set 323 has the potential to be used for mining phylogenetically informative genetic data from 324 assemblies obtained from shotgun sequencing experiments. Used in combination with non325 destructive DNA extraction protocols, our UCE baits could also be used to obtain sequence 326 data from material that cannot be damaged, such as specimens from type series. This approach 327 was successfully applied to centuries-old museum specimens such as Opiliones, carpenter bees, 328 and weevils (Blaimer et al., 2016; Van Dam et al., 2017; Derkarabetian et al., 2019). We 329 recently sequenced the mitochondrial genome of a Syntype of the termite Archotermopsis 330 wroughtoni collected at the end of the $19^{\text {th }}$ century (Wang et al., 2021). Termite UCEs could 331 be extracted using the same procedures. Termite taxonomy, which is led by a shrinking pool of 332 experts and is largely based on soldier and worker gut morphology, could benefit from the use 333 of the many UCE markers designed in this study (Eggleton, 1999; Korb et al., 2019). UCE 334 baiting from whole-genome shotgun sequencing is the perfect tool to carry out a global 335 taxonomic revision of termites. 
bioRxiv preprint doi: https://doi.org/10.1101/2021.12.09.472027; this version posted December 17, 2021. The copyright holder for this preprint (which was not certified by peer review) is the author/funder, who has granted bioRxiv a license to display the preprint in perpetuity. It is made available under aCC-BY-NC-ND 4.0 International license.

UCEs in termites

\section{References}

Allio, R., Schomaker-Bastos, A., Romiguier, J., Prosdocimi, F., Nabholz, B., Delsuc, F. 2020. MitoFinder: efficient automated large-scale extraction of mitogenomic data in target enrichment phylogenomics. Molecular Ecology Resources 20: 892-905.

Bejerano, G., Pheasant, M., Makunin, I., Stephen, S., Kent, W.J., Mattick, J.S., Haussler, D. 2004. Ultraconserved elements in the human genome. Science 304: 1321-1325.

Blaimer, B.B., Lloyd, M.W., Guillory, W.X., Brady, S.G. 2016. Sequence capture and phylogenetic utility of genomic ultraconserved elements obtained from pinned insect specimens. PLOS ONE 11: e0161531.

Blom, M.P.K., Bragg, J.G., Potter, S., Moritz, C. 2017. Accounting for uncertainty in gene tree estimation: summary-coalescent species tree inference in a challenging radiation of Australian lizards. Systematic Biology 66: 352-366.

Bourguignon, T., Lo, N., Cameron, S.L., Šobotník, J., Hayashi, Y., Shigenobu, S., Watanabe, D., Roisin, Y., Miura, T., Evans, T.A. 2015. The evolutionary history of termites as inferred from 66 mitochondrial genomes. Molecular Biology and Evolution 32: 406-421.

Bourguignon, T., Lo, N., Šobotník, J., Ho, S.Y.W., Iqbal, N., Coissac, É., Lee, M., Jendryka, M.M., Sillam-Dussès, D., Kř́̌žková, B., Roisin, Y., Evans, T.A. 2017. Mitochondrial phylogenomics resolves the global spread of higher termites, ecosystem engineers of the tropics. Molecular Biology and Evolution 34: 589-597.

Bucek, A., Šobotník, J., He, S., Shi, M., McMahon, D.P., Holmes, E.C., Roisin, Y., Lo, N., Bourguignon, T. 2019. Evolution of termite symbiosis informed by transcriptome-based phylogenies. Current Biology 29: 3728-3734.e4. 
bioRxiv preprint doi: https://doi.org/10.1101/2021.12.09.472027; this version posted December 17, 2021. The copyright holder for this preprint (which was not certified by peer review) is the author/funder, who has granted bioRxiv a license to display the preprint in perpetuity. It is made available under aCC-BY-NC-ND 4.0 International license.

UCEs in termites

Cameron, S.L. 2014. Insect mitochondrial genomics: implications for evolution and phylogeny. Annual Review of Entomology 59: 95-117.

Cameron, S.L., Lo, N., Bourguignon, T., Svenson, G.J., Evans, T.A. 2012. A mitochondrial genome phylogeny of termites (Blattodea: Termitoidae): robust support for interfamilial relationships and molecular synapomorphies define major clades. Molecular Phylogenetics and Evolution 65: 163-173.

Castresana, J. 2000. Selection of conserved blocks from multiple alignments for their use in phylogenetic analysis. Molecular Biology and Evolution 17: 540-552.

Chen, S., Zhou, Y., Chen, Y., Gu, J. 2018. Fastp: an ultra-fast all-in-one FASTQ preprocessor. Bioinformatics 34: i884-i890.

Chernomor, O., Von Haeseler, A., Minh, B.Q. 2016. Terrace aware data structure for phylogenomic inference from supermatrices. Systematic Biology 65: 997-1008.

Degnan, J.H., Rosenberg, N.A. 2009. Gene tree discordance, phylogenetic inference and the multispecies coalescent. Trends in Ecology and Evolution 24: 332-340.

Derkarabetian, S., Benavides, L.R., Giribet, G. 2019. Sequence capture phylogenomics of historical ethanol-preserved museum specimens: unlocking the rest of the vault. Molecular Ecology Resources 19: 1531-1544.

Eggleton, P. 1999. Termite species description rates and the state of termite taxonomy. Insectes Sociaux 46: 1-5.

Engel, M.S., Grimaldi, D.A., Krishna, K. 2009. Termites (Isoptera): their phylogeny, classification, and rise to ecological dominance. American Museum Novitates 3650: 1-27. 
bioRxiv preprint doi: https://doi.org/10.1101/2021.12.09.472027; this version posted December 17, 2021. The copyright holder for this preprint (which was not certified by peer review) is the author/funder, who has granted bioRxiv a license to display the preprint in perpetuity. It is made available under aCC-BY-NC-ND 4.0 International license.

UCEs in termites Cambay amber, with the earliest record of the Termitidae (Isoptera). ZooKeys 148: 105123.

Faircloth, B.C. 2017. Identifying conserved genomic elements and designing universal bait sets to enrich them. Methods in Ecology and Evolution 8: 1103-1112.

Faircloth, B.C. 2016. PHYLUCE is a software package for the analysis of conserved genomic loci. Bioinformatics 32: 786-788.

Faircloth, B.C., Branstetter, M.G., White, N.D., Brady, S.G. 2015. Target enrichment of ultraconserved elements from arthropods provides a genomic perspective on relationships among Hymenoptera. Molecular Ecology Resources 15: 489-501.

Faircloth, B.C., McCormack, J.E., Crawford, N.G., Harvey, M.G., Brumfield, R.T., Glenn, T.C. 2012. Ultraconserved elements anchor thousands of genetic markers spanning multiple evolutionary timescales. Systematic Biology 61: 717-726.

Grimaldi, D.A., Engel, M.S. 2005. Evolution of the Insects. Cambridge University Press, Cambridge.

Gurevich, A., Saveliev, V., Vyahhi, N., Tesler, G. 2013. QUAST: quality assessment tool for genome assemblies. Bioinformatics 29: 1072-1075.

Harris, R.S. 2007. Improved pairwise alignment of genomic DNA. The Pennsylvania State University.

Hoang, D.T., Chernomor, O., von Haeseler, A., Minh, B.Q., Vinh, L.S. 2018. UFBoot2: improving the ultrafast bootstrap approximation. Molecular Biology and Evolution 35: 518-522. 
bioRxiv preprint doi: https://doi.org/10.1101/2021.12.09.472027; this version posted December 17, 2021. The copyright holder for this preprint (which was not certified by peer review) is the author/funder, who has granted bioRxiv a license to display the preprint in perpetuity. It is made available under aCC-BY-NC-ND 4.0 International license.

UCEs in termites simulator. Bioinformatics 28: 593-594.

403 404 405

Inward, D.J.G., Vogler, A.P., Eggleton, P. 2007. A comprehensive phylogenetic analysis of termites (Isoptera) illuminates key aspects of their evolutionary biology. Molecular Phylogenetics and Evolution 44: 953-967.

Kalyaanamoorthy, S., Minh, B.Q., Wong, T.K.F., Von Haeseler, A., Jermiin, L.S. 2017. ModelFinder: fast model selection for accurate phylogenetic estimates. Nature Methods 14: 587-589.

Katoh, K., Standley, D.M. 2013. MAFFT multiple sequence alignment software version 7: improvements in performance and usability. Molecular Biology and Evolution 30: 772780.

Kent, W.J. 2002. BLAT_-The BLAST-like alignment tool. Genome Research 12: 656-664.

Korb, J., Kasseney, B.D., Cakpo, Y.T., Casalla Daza, R.H., Gbenyedji, J.N.K.B., Ilboudo, M.E., Josens, G., Koné, N.A., Meusemann, K., Ndiaye, A.B., Okweche, S.I., Poulsen, M., Roisin, Y., Sankara, F. 2019. Termite taxonomy, challenges and prospects: West Africa, a case example. Insects 10: 32 .

Kück, P., Longo, G.C. 2014. FASconCAT-G: extensive functions for multiple sequence alignment preparations concerning phylogenetic studies. Frontiers in Zoology 11: 81.

Legendre, F., Whiting, M.F., Bordereau, C., Cancello, E.M., Evans, T. a., Grandcolas, P. 2008. The phylogeny of termites (Dictyoptera: Isoptera) based on mitochondrial and nuclear markers: Implications for the evolution of the worker and pseudergate castes, and foraging behaviors. Molecular Phylogenetics and Evolution 48: 615-627.

Li, H., Handsaker, B., Wysoker, A., Fennell, T., Ruan, J., Homer, N., Marth, G., Abecasis, G., 
bioRxiv preprint doi: https://doi.org/10.1101/2021.12.09.472027; this version posted December 17, 2021. The copyright holder for this preprint (which was not certified by peer review) is the author/funder, who has granted bioRxiv a license to display the preprint in perpetuity. It is made available under aCC-BY-NC-ND 4.0 International license.

UCEs in termites

Durbin, R. 2009. The Sequence Alignment/Map format and SAMtools. Bioinformatics 25: 2078-2079.

Lo, N., Kitade, O., Miura, T., Constantino, R., Matsumoto, T. 2004. Molecular phylogeny of the Rhinotermitidae. Insectes Sociaux 51: 365-371.

Lunter, G., Goodson, M. 2011. Stampy: a statistical algorithm for sensitive and fast mapping of Illumina sequence reads. Genome Research 21: 936-939.

Nguyen, L.T., Schmidt, H.A., Von Haeseler, A., Minh, B.Q. 2015. IQ-TREE: a fast and effective stochastic algorithm for estimating maximum-likelihood phylogenies. Molecular Biology and Evolution 32: 268-274.

Nurk, S., Meleshko, D., Korobeynikov, A., Pevzner, P.A. 2017. metaSPAdes: a new versatile metagenomic assembler. Genome Research 27: 824-834.

Parins-Fukuchi, C., Stull, G.W., Smith, S.A. 2021. Phylogenomic conflict coincides with rapid morphological innovation. Proceedings of the National Academy of Sciences of the United States of America 118: e2023058118.

Quattrini, A.M., Faircloth, B.C., Dueñas, L.F., Bridge, T.C.L., Brugler, M.R., Calixto-Botía, I.F., DeLeo, D.M., Forêt, S., Herrera, S., Lee, S.M.Y., Miller, D.J., Prada, C., RádisBaptista, G., Ramírez-Portilla, C., Sánchez, J.A., Rodríguez, E., McFadden, C.S. 2018. Universal target-enrichment baits for anthozoan (Cnidaria) phylogenomics: new approaches to long-standing problems. Molecular Ecology Resources 18: 281-295.

Quinlan, A.R., Hall, I.M. 2010. BEDTools: a flexible suite of utilities for comparing genomic features. Bioinformatics 26: 841-842.

Rice, P., Longden, L., Bleasby, A. 2000. EMBOSS: the European Molecular Biology Open 
bioRxiv preprint doi: https://doi.org/10.1101/2021.12.09.472027; this version posted December 17, 2021. The copyright holder for this preprint (which was not certified by peer review) is the author/funder, who has granted bioRxiv a license to display the preprint in perpetuity. It is made available under aCC-BY-NC-ND 4.0 International license.

UCEs in termites Software Suite. Trends in Genetics 16: 276-277.

447

Ryu, T., Seridi, L., Ravasi, T. 2012. The evolution of ultraconserved elements with different phylogenetic origins. BMC Evolutionary Biology 12: 236.

Sayyari, E., Mirarab, S. 2016. Fast coalescent-based computation of local branch support from quartet frequencies. Molecular Biology and Evolution 33: 1654-1668.

Simão, F.A., Waterhouse, R.M., Ioannidis, P., Kriventseva, E. V., Zdobnov, E.M. 2015. BUSCO: assessing genome assembly and annotation completeness with single-copy orthologs. Bioinformatics 31: 3210-3212.

Smit, A.F.A., Hubley, R., Green, P. 2015. RepeatMasker Open-4.0 2013-2015.

Smith, B.T., Harvey, M.G., Faircloth, B.C., Glenn, T.C., Brumfield, R.T. 2014. Target capture and massively parallel sequencing of ultraconserved elements for comparative studies at shallow evolutionary time scales. Systematic Biology 63: 83-95.

Smith, S.A., Moore, M.J., Brown, J.W., Yang, Y. 2015. Analysis of phylogenomic datasets reveals conflict, concordance, and gene duplications with examples from animals and plants. BMC Evolutionary Biology 15: 150. BMC Evolutionary Biology.

Suyama, M., Torrents, D., Bork, P. 2006. PAL2NAL: robust conversion of protein sequence alignments into the corresponding codon alignments. Nucleic Acids Research 34: W609W612.

Talavera, G., Castresana, J. 2007. Improvement of phylogenies after removing divergent and ambiguously aligned blocks from protein sequence alignments. Systematic Biology 56: 564-577.

Thorne, B.L., Grimaldi, D.A., Krishna, K. 2000. Early fossil history of the termites. In: 
bioRxiv preprint doi: https://doi.org/10.1101/2021.12.09.472027; this version posted December 17, 2021. The copyright holder for this preprint (which was not certified by peer review) is the author/funder, who has granted bioRxiv a license to display the preprint in perpetuity. It is made available under aCC-BY-NC-ND 4.0 International license.

UCEs in termites

468

469

470

471

472

473

474

475

476

477

478

479

480

481

482

483

484

485

486

Termites: Evolution, Sociality, Symbioses, Ecology (T. Abe, D. E. Bignell, \& M. Higashi, eds), pp. 77-93. Kluwer Academic Publishers, Dordrecht, The Netherlands.

Van Dam, M.H., Lam, A.W., Sagata, K., Gewa, B., Laufa, R., Balke, M., Faircloth, B.C., Riedel, A. 2017. Ultraconserved elements (UCEs) resolve the phylogeny of Australasian smurfweevils. PLOS ONE 12: e0188044.

Wang, M., Hellemans, S., Šobotník, J., Arora, J., Buček, A., Sillam-Dussès, D., Clitheroe, C., Lu, T., Lo, N., Engel, M.S., Roisin, Y., Evans, T.A., Bourguignon, T. 2021. Historical biogeography of early diverging termite lineages (Isoptera: Teletisoptera). bioRxiv 2021.12.02.471008.

White, N.D., Braun, M.J. 2019. Extracting phylogenetic signal from phylogenomic data: higher-level relationships of the nightbirds (Strisores). Molecular Phylogenetics and Evolution 141: 106611.

Whitfield, J.B., Lockhart, P.J. 2007. Deciphering ancient rapid radiations. Trends in Ecology and Evolution 22: 258-265.

Zhang, C., Rabiee, M., Sayyari, E., Mirarab, S. 2018. ASTRAL-III: polynomial time species tree reconstruction from partially resolved gene trees. BMC Bioinformatics 19: 153.

Zhang, Y.M., Williams, J.L., Lucky, A. 2019. Understanding UCEs: a comprehensive primer on using ultraconserved elements for arthropod phylogenomics. Insect Systematics and Diversity 3: 3. 
bioRxiv preprint doi: https://doi.org/10.1101/2021.12.09.472027; this version posted December $17,2021$. The copyright holder for this

preprint (which was not certified by peer review) is the author/funder, who has granted bioRxiv a license to display the preprint in perpetuity. It is made available under aCC-BY-NC-ND 4.0 International license.

UCEs in termites

\section{Figure captions}

489 Figure 1: (A) Maximum likelihood phylogenetic tree of termites reconstructed with IQ-TREE 490 using 5,934 UCE loci and complete mitochondrial genomes. Only UCE loci present in more 491 than $75 \%$ of species were used. Support values are indicated for non-fully resolved nodes: 492 ultrafast bootstrap (UFB; summarized from the phylogenetic trees reconstructed using UCE 493 only and UCE + mitochondrial DNA displayed in Figures S3 and S4, respectively) and 494 ASTRAL-III local posterior probabilities (LPP; phylogenetic tree displayed in Figure S5) 495 values. (B) Family-level summary topology of termites supported by both UCEs (this study) 496 and transcriptomic data (Bucek et al., 2019), with the indication of alternative topologies 497 inferred from mitochondrial genome data alone (Bourguignon et al., 2015, 2017). Unsupported 498 splits were summarized as polytomies (branches in red). 


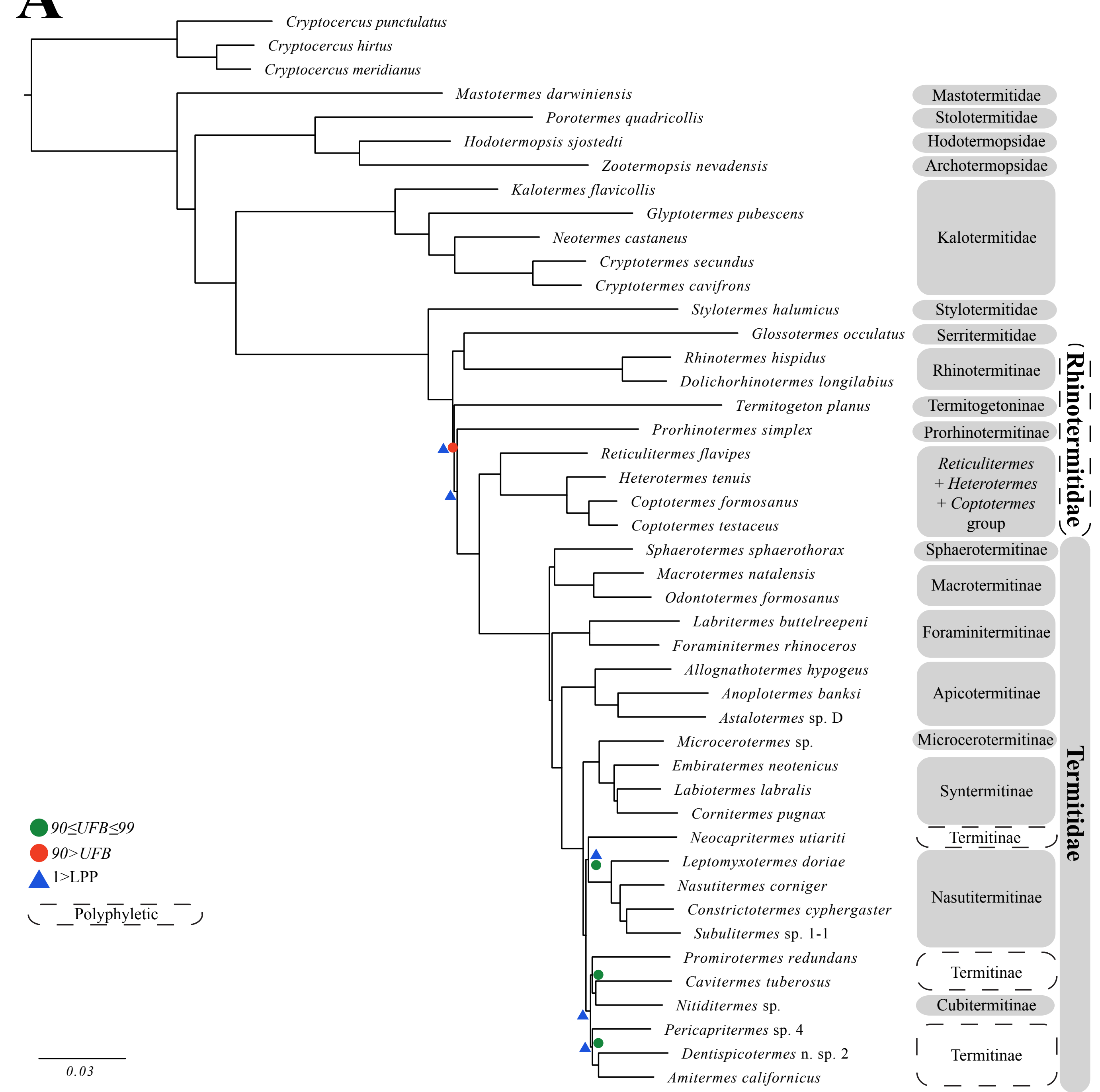

$90>U F$

$\triangle 1>$ LPP

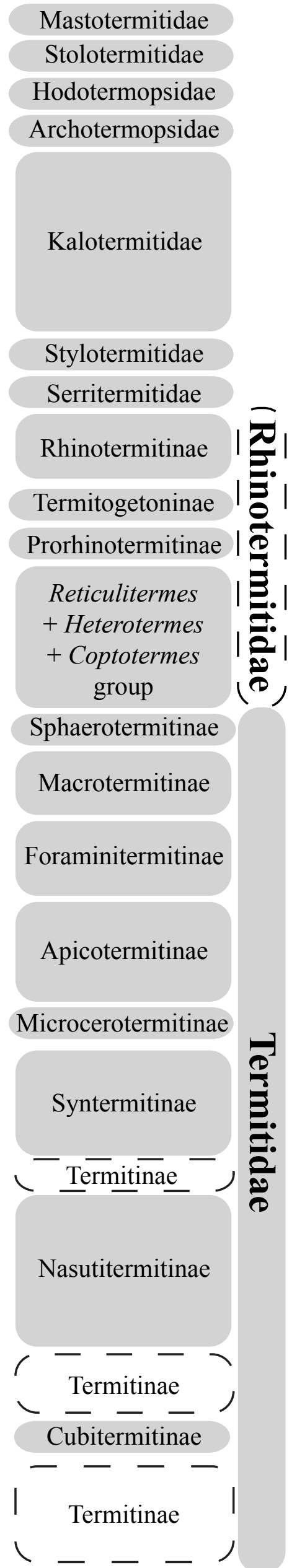

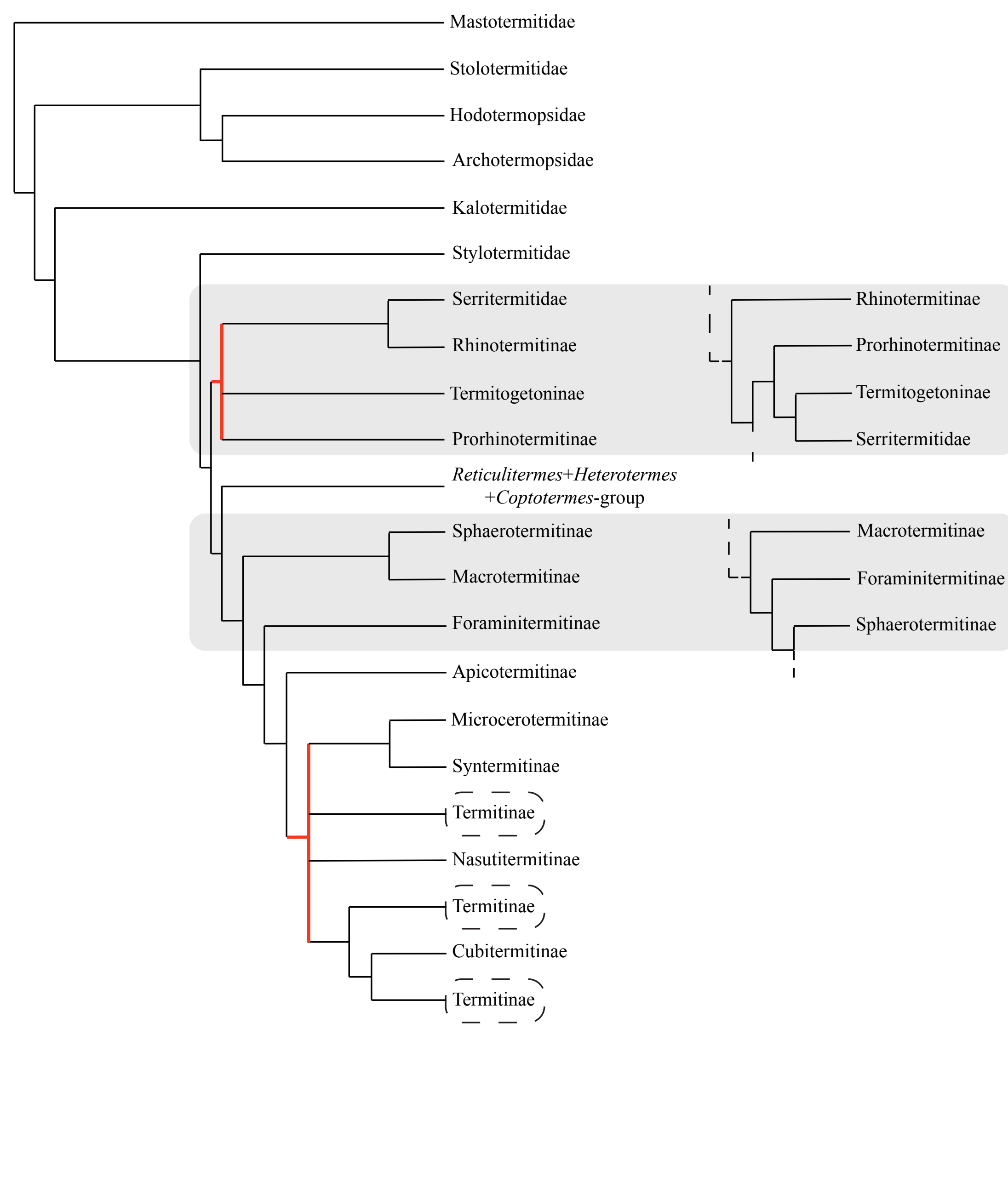

